Prepared for the U.S. Department of Energy

under Contract DE-AC05-76RL01830

\title{
MARS June 2012 Flight Data: Natural Background and Point Source Spectra
}
SC Stave
JM Benz
KE Dorow
JA Willett
BD Glasgow

November 2012

\section{Pacific Northwest}

NATIONAL LABORATORY

Proudly Operated by Battelle Since 1965 


\title{
DISCLAIMER
}

This report was prepared as an account of work sponsored by an agency of the United States Government. Neither the United States Government nor any agency thereof, nor Battelle Memorial Institute, nor any of their employees, makes any warranty, express or implied, or assumes any legal liability or responsibility for the accuracy, completeness, or usefulness of any information, apparatus, product, or process disclosed, or represents that its use would not infringe privately owned rights. Reference herein to any specific commercial product, process, or service by trade name, trademark, manufacturer, or otherwise does not necessarily constitute or imply its endorsement, recommendation, or favoring by the United States Government or any agency thereof, or Battelle Memorial Institute. The views and opinions of authors expressed herein do not necessarily state or reflect those of the United States Government or any agency thereof.

\author{
PACIFIC NORTHWEST NATIONAL LABORATORY \\ operated by \\ BATTELLE \\ for the \\ UNITED STATES DEPARTMENT OF ENERGY \\ under Contract DE-AC05-76RL01830
}

Printed in the United States of America
Available to DOE and DOE contractors from the Office of Scientific and Technical Information,
P.O. Box 62, Oak Ridge, TN 37831-0062;
ph: (865) 576-8401
fax: $(865)$ 576-5728
email: reports@adonis.osti.gov

\begin{abstract}
Available to the public from the National Technical Information Service, U.S. Department of Commerce, 5285 Port Royal Rd., Springfield, VA 22161 ph: (800) 553-6847 fax: $(703) 605-6900$ email: orders@ntis.fedworld.gov online ordering: http://www.ntis.gov/ordering.htm
\end{abstract}

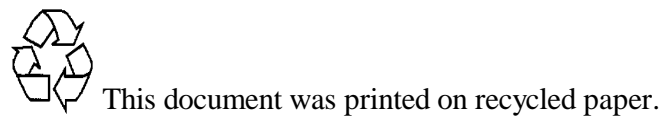


PNNL-21978

\title{
MARS June 2012 Flight Data: Natural Background and Point Source Spectra
}

\author{
SC Stave \\ JM Benz \\ KE Dorow \\ JA Willett \\ BD Glasgow
}

November 2012

Prepared for the U.S. Department of Energy under Contract DE-AC05-76RL01830

Pacific Northwest National Laboratory

Richland, Washington 99352 


\section{Abstract}

This brief document describes the electronic data that were collected by the Multi-sensor Aerial Radiation Survey (MARS) detector in June 2012 while mounted onboard the RSL Bell-412 helicopter. A copy of the data is included as an electronic appendix. 


\section{Symbols, Acronyms and/or Initialisms}

AGL

AMS

ASCII

GPS

HPGe

LN

MARS

NNSS

PNNL

RSL

UTC

\author{
Above Ground Level \\ Aerial Measuring Systems \\ American Standard Code for Information Interchange \\ Global Positioning System \\ High Purity Germanium \\ Liquid Nitrogen \\ Multi-sensor Airborne Radiation Survey \\ Nevada National Security Site \\ Pacific Northwest National Laboratory \\ Remote Sensing Laboratory \\ Coordinated Universal Time
}




\section{Contents}

$\begin{array}{llr}\begin{array}{l}\text { Abstract } \\ \text { Symbols, Acronyms and/or Initialisms }\end{array} & \mathbf{1} \\ \text { Figures } & & \mathbf{2} \\ \text { Introduction } & & \mathbf{4} \\ \mathbf{1 . 0} & \text { Detector Description } & \mathbf{6} \\ 1.1 & \text { The MARS detector } & 6 \\ 1.2 & \text { Calibration and Summing } & 7 \\ 2.0 & \text { Measurement Campaign Overview } & \mathbf{7} \\ 2.1 & \text { Point Sources } & 7 \\ 2.2 & \text { Natural, highly variable background } & 8 \\ 2.3 & \text { Background variation with altitude } & 8 \\ 3.0 & \text { Data Format } & \mathbf{9} \\ \mathbf{4 . 0} & \text { Known Systematic Errors } & \mathbf{1 0} \\ \mathbf{5 . 0} & \text { Conclusion } & \mathbf{1 1} \\ \mathbf{6 . 0} & \text { Acknowledgements } & \mathbf{1 1} \\ \mathbf{7 . 0} & \text { Appendix } & \mathbf{1 1} \\ \mathbf{8 . 0} & \text { References } & \mathbf{1 1}\end{array}$




\section{Figures}

Figure 1. Left: The MARS detector in the helicopter mount. Right: The MARS detector and electronics mounted in the helicopter.

Figure 2. Location of the MARS detector and electronics relative to the fuel tanks.......................6

Figure 3. MARS Gross counts from the Government Wash survey ….......................................... 8

Figure 4. Flight path of the Lake Mohave altitude profile ........................................................... 


\section{Introduction}

In June 2012, the Multi-sensor Airborne Radiation Survey (MARS) detector was taken to the Remote Sensing Laboratory-Nellis in Las Vegas, NV and flown onboard the RSL Bell-412 helicopter. This report briefly summarizes the flights, the data taken, and the format of the data included in the Appendix. 


\subsection{Detector Description}

\subsection{The MARS detector}

The MARS detector is an array of 14 high purity Germanium (HPGe) crystals located in a single cryostat. The system is described in more detail in Ref. [1]. The MARS system had previously been operated on boats and trucks and was modified for use on a helicopter. The MARS detector in its helicopter mount is shown in Figure 1. MARS requires approximately 5.5 liters of liquid nitrogen (LN) to maintain the proper operational temperature for the HPGe crystals. In the laboratory, this quantity of LN will last 42 hours in the vertical orientation.
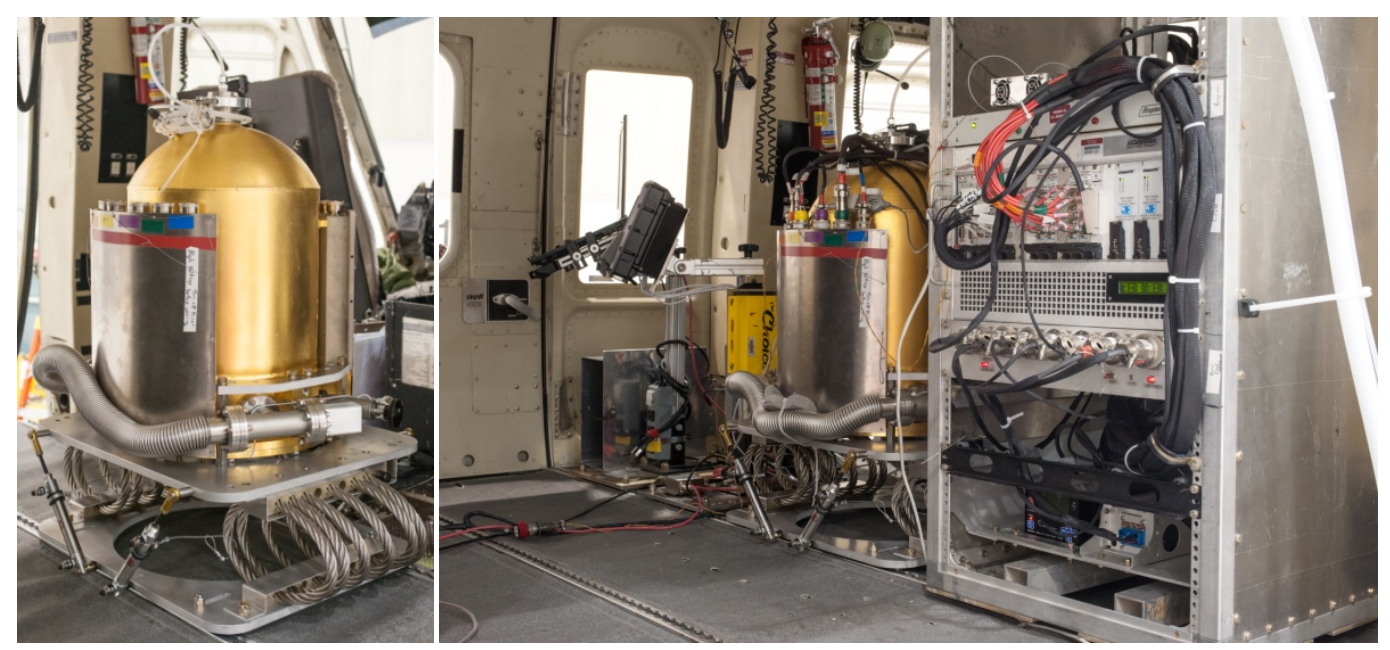

Figure 1. Left: The MARS detector in the helicopter mount. Right: The MARS detector and electronics mounted in the helicopter.

The MARS detector was placed on the central axis of the helicopter, between the two fuel cells (see Figure 2).

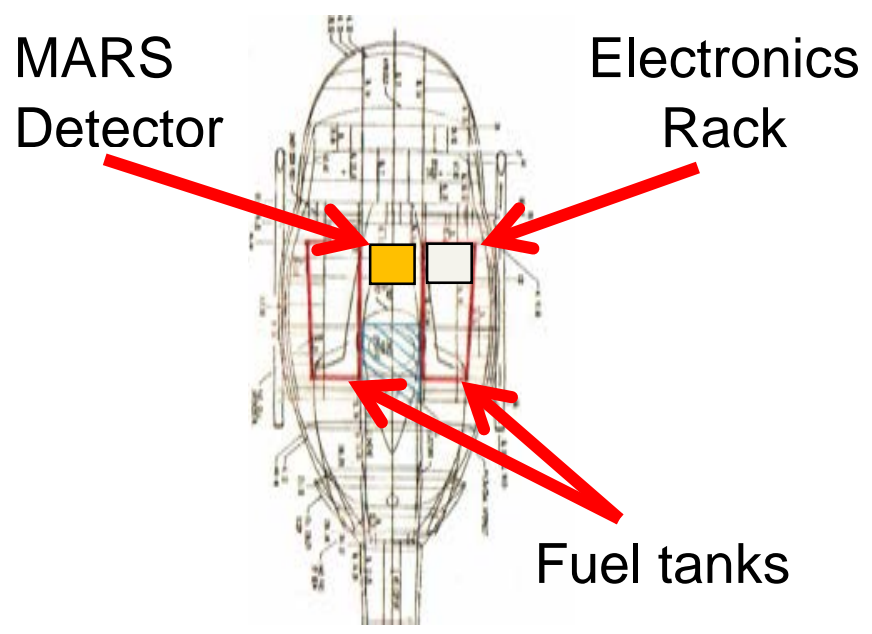

Figure 2. Location of the MARS detector and electronics relative to the fuel tanks. 


\subsection{Calibration and Summing}

The MARS detector was calibrated using check sources at RSL. The same calibration using the $356 \mathrm{keV}$ line from Ba-133 and the $1333 \mathrm{keV}$ line from Co-60 has been applied to all of the data. In addition, all of the data presented in this document are the result of a simple sum of the active crystals in the detector. The crystal number scheme is as follows:

- Crystals closest to the front window are 0 through 6 with 0 being in the center.

- Crystals farther from the window are 8 through 14 with 8 being in the center.

Crystal 6 cannot be biased and so is ignored in the analysis. Crystals 9 and 10 are underbiased but do provide some additional efficiency and so have been included in these data sets. Their inclusion could degrade the resolution by a small amount.

\subsection{Measurement Campaign Overview}

The data for three test flights are included in the appendix of this report. The three flights are described below.

\subsection{Point Sources}

For this test of the MARS detector with point sources, the helicopter flew at 70 knots ground speed and the altitude varied from 50, 100, 150, 200, 300, and 500 feet. Each measurement was repeated multiple times to give the option of checking consistency or combining multiple passes for increased statistics. The three lowest altitude passes were performed first and repeated 8 times. The remaining higher altitude passes were performed second. Due to time constraints, the high higher altitude passes were only repeated 4 times each.

Four sources were placed on the 7500 foot long runway at the Desert Rock Airport adjacent to the Nevada National Security Site (NNSS). The source location and strengths are listed in Table 1. Note that two Am-241 sources were used in order to increase the total activity. Since the threshold of the MARS detector is significantly above the $60 \mathrm{keV}$ gamma-ray line from Am-241, it is not expected that it will be observed.

Table 1 . The source locations and strengths aged to $6 / 20 / 2012$

\begin{tabular}{|c|c|c|c|}
\hline Source & Activity & Latitude & Longitude \\
\hline Cs-137 & $25.3 \mathrm{mCi}$ & 36.6148288 & -116.0367795 \\
\hline Co-60 & $4.13 \mathrm{mCi}$ & 36.6182293 & -116.0339139 \\
\hline Ba-133 & $7.05 \mathrm{mCi}$ & 36.6216510 & -116.0310596 \\
\hline Am-241 & $9.39+9.47 \mathrm{mCi}$ & 36.6249856 & -116.0282504 \\
\hline
\end{tabular}




\subsection{Natural, highly variable background}

Located approximately 10 miles west of Las Vegas is the Government Wash area. This area is characterized by highly variable natural background. The area has been surveyed extensively as it has been used to characterize the Aerial Measuring Systems (AMS) response to extended sources. The flight lines used for the June 2012 survey were $100 \mathrm{ft}$ AGL altitude and $200 \mathrm{ft}$ line spacing with the helicopter ground speed of 70 knots.

A plot of the gross counts observed by the MARS detector integrated from 200 to $3069 \mathrm{keV}$ is shown in Figure 3. The bread crumb map has been interpolated using a nearest neighbors inverse distance weighting approach. No altitude corrections have been applied and helicopter turn data was not excluded.

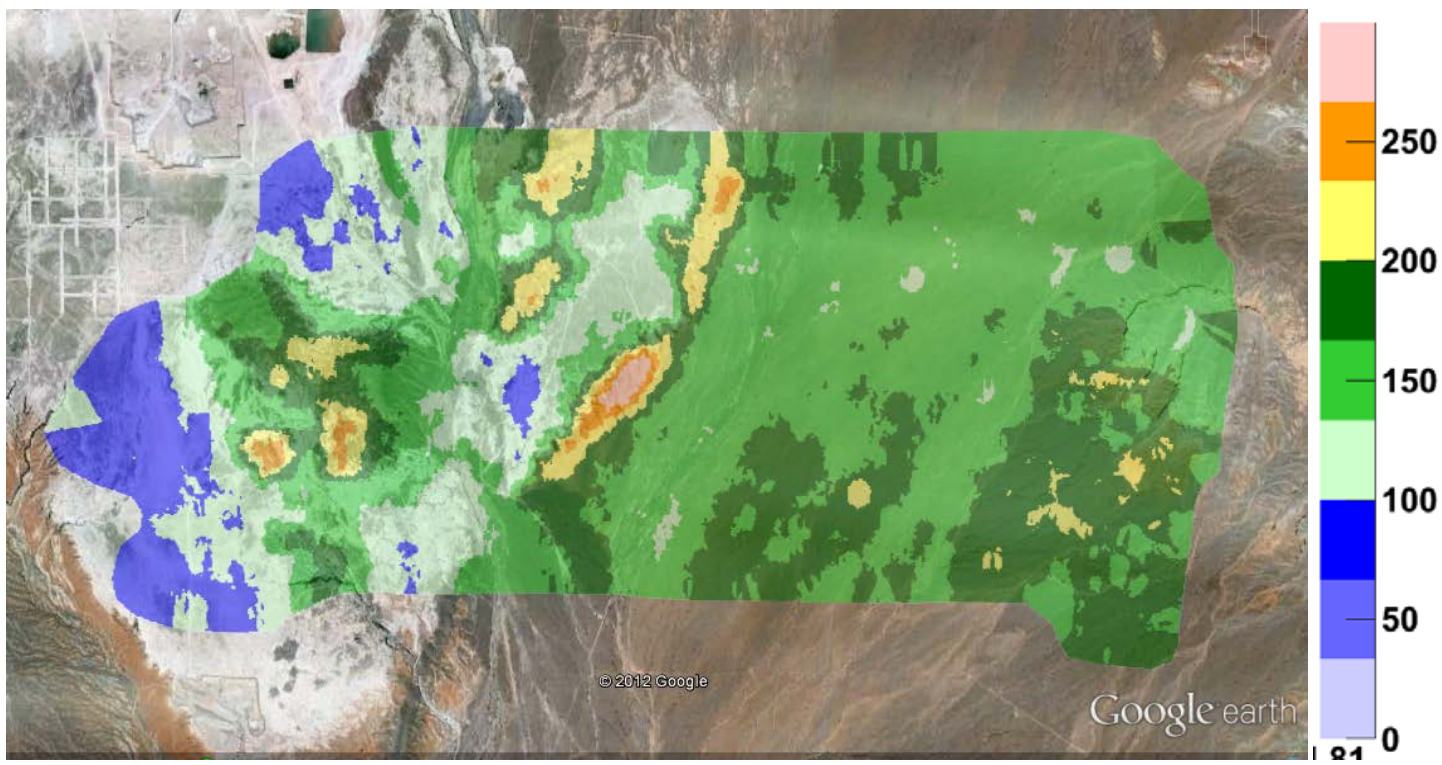

Figure 3. MARS Gross counts from the Government Wash survey.

\subsection{Background variation with altitude}

Another standard AMS flight is the Altitude Spiral. The average attenuation of gamma-rays in air and the cosmic ray component of the spectrum can be determined by flying the same path over water and land at various altitudes. The standard AMS Altitude Spiral is performed at Lake Mohave, approximately 60 
miles south of Las Vegas. Each water and land line was approximately 2 miles long and was flown at 70 knots at altitudes of 50, 150, 300, 500, 1000, and 3000 feet. The bread crumb map of the MARS system over Lake Mohave is shown in Figure 4.

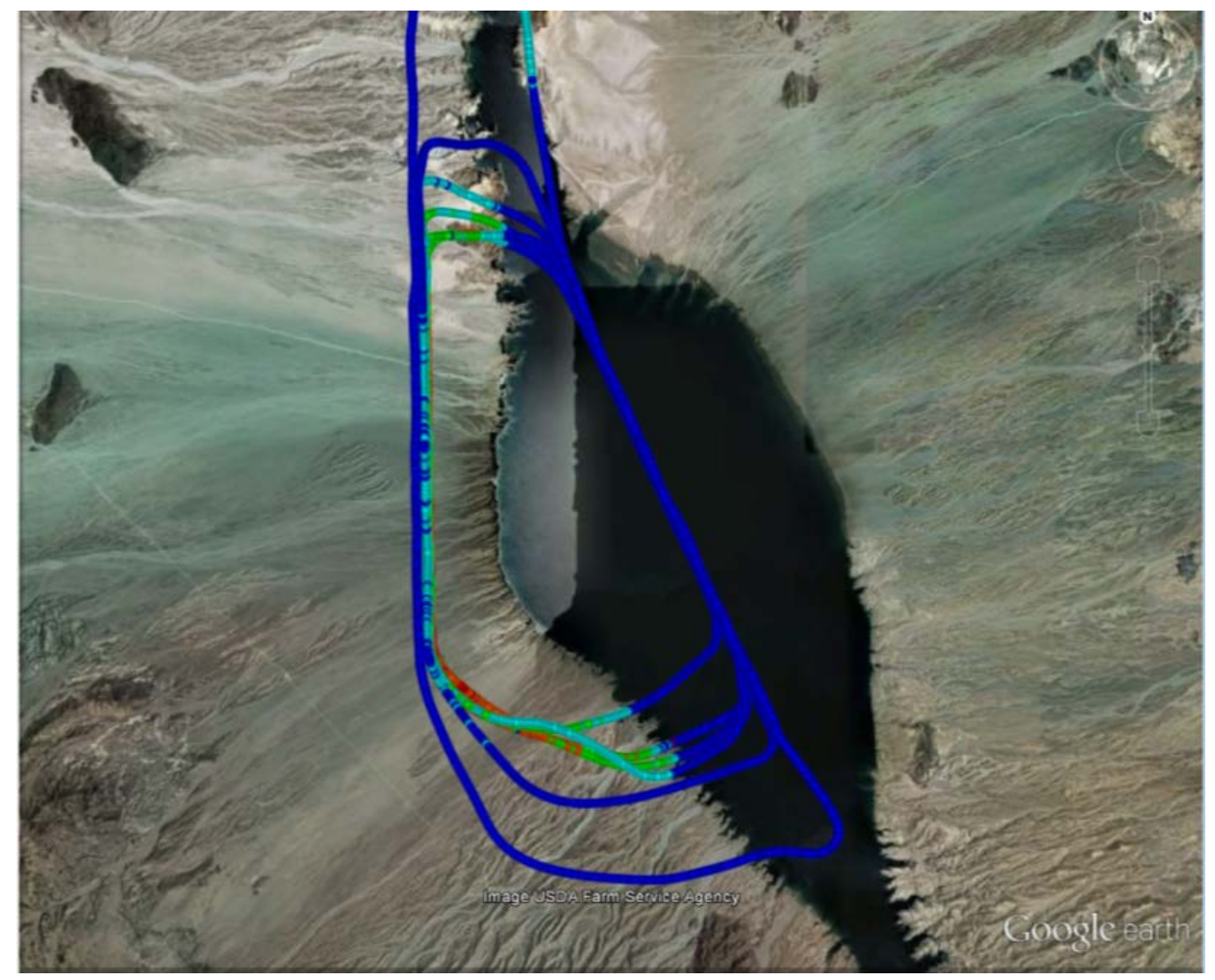

Figure 4. Flight path of the Lake Mohave altitude profile.

\subsection{Data Format}

The data for each of the four flights are in separate ASCII files in 1 second time slices. Each line of the file represents 1 second of flight time. Each field in the file is separated by a comma. The first line of each file describes the contents of that column of data.

Table 2. Location and time information format

\begin{tabular}{|c|c|c|c|c|c|c|c|}
\hline $\begin{array}{l}\text { Sequence } \\
\text { Number }\end{array}$ & $\begin{array}{l}\text { GPS UTC Date } \\
\text { MM/DD/YYYY }\end{array}$ & $\begin{array}{l}\text { GPS UTC } \\
\text { Time } \\
\text { hh:mm:ss }\end{array}$ & $\begin{array}{l}\text { Acquisition } \\
\text { time }(\mu \mathrm{s})\end{array}$ & Longitude & Latitude & $\begin{array}{l}\text { GPS } \\
\text { Altitude } \\
\text { above } \\
\text { mean sea } \\
\text { level(m) }\end{array}$ & $\begin{array}{l}\text { Altitude } \\
\text { from } \\
\text { Radar } \\
\text { Altimeter } \\
\text { (m) }\end{array}$ \\
\hline
\end{tabular}

After the location and time information are given, the GPS fix quality information is given as reported by the GPS receiver: 
Table 3. GPS data quality information

\begin{tabular}{|l|l|l|}
\hline GPS Fix quality & Number of tracked satellites & Horizontal dilution of position \\
\hline
\end{tabular}

The GPS GGA format gives the GPS fix quality codes as:

0 = invalid

$1=$ GPS fix (SPS)

$2=$ DGPS fix

3 = PPS fix

4 = Real Time Kinematic

5 = Float RTK

6 = estimated (dead reckoning) (2.3 feature)

7 = Manual input mode

8 = Simulation mode

After the GPS data quality information is given, the contents of 1024 bins from 0 to $3072 \mathrm{keV}$ are given. The first line of the file gives the value corresponding to the center of the bin.

The acquisition time is the live time estimated by the Pixie- 4 digitizer cards in the data acquisition system for the one second bin averaged over all the data acquisition channels. It is typically greater than $98 \%$ live.

\subsection{Known Systematic Errors}

While analyzing the data, several systematic errors have been discovered. The following have been accounted for:

- Radar altimeter calibration: The conversion factor for the radar altimeter was assumed to be $-0.004 \mathrm{ft} / \mathrm{V}$ with no offset.

- Synchronization of HPGe and GPS/Radar Altimeter data streams: An initial offset and timedependent offset were discovered in the data. This was corrected for using the point source data. The inherent uncertainty in the GPS location is therefore increased due to the possibility that the spectrum corresponds to the adjacent GPS sample.

- Synchronization of HPGe data and live time information: A statistics file with the live time information is generated separately each second based on the forced buffer dumps. The number for each buffer dump was used to determine the appropriate estimated live time for that second of data collection. The live time is estimated by the Pixie- 4 digitizer cards as the data are taken (see Ref. [2] for more details). The live time reported in the data file is the result of averaging the live times for each individual channel in a buffer dump, an acceptable approximation due to the method with which the cards are read out. That live time is then reported for the one second time bin that it corresponds to. The live time appears to be synchronized to \pm 1 second but robust testing of this has not been performed. For example, when the gross count rate increases rapidly, 
after the correction, the live time decreases at the same time. In addition, the data acquisition system may be busy for other reasons causing a drop in the measured live time. Many of these correlations have been observed in the corrected data within 1 second of each other giving more confidence in the data stream synchronization. Note that the GPS and radar altimeter uncertainty have approximately the same timing uncertainty as well.

\subsection{Conclusion}

The data in the appendix contain all of the relevant information from three June 2012 MARS survey flights conducted on the RSL Bell-412 helicopter. With the appropriate caveats, the data can be used to generate spectra and maps of gross counts or isotopic activities.

\subsection{Acknowledgements}

PNNL is operated for the U.S. Department of Energy by Battelle Memorial Institute under Contract DEAC06-76RLO 1830. This work was funded by the Office of Defense Nuclear Nonproliferation, Office of Nonproliferation Research and Development (NA-22).

\subsection{Appendix}

- MARS Altitude Spiral, June 18, 2012: MARS_June2012_AltSpiral.dat

- MARS Point Source Survey, June 19, 2012: MARS_June2012_DRock.dat

- MARS Government Wash Survey, June 20, 2012: MARS_June2012_GWash.dat

\subsection{References}

1. Fast, J.E., et al., The multi-sensor airborne radiation survey (MARS) instrument. Nucl. Inst. Meth. A, 2012.

2. XIA, User's Manual Digital Gamma Finder (DGF) Pixie-4 Version 2.01. 2009, XIA LLC: Hayward, CA. 